\title{
Challenges and barriers faced by women in accessing justice against obstetric violence
}

\author{
Chandramathi Majety $^{1}$, Sravani Bejugam ${ }^{2}$
}

\author{
${ }^{1}$ Symbiosis Law School, Hyderabad, India \\ ${ }^{2}$ Sri Chaitanya Junior College, Marredpally Branch, Secunderabad, Telangana, India
}

Received: 06 July 2016

Revised: 06 August 2016

Accepted: 10 August 2016

\author{
*Correspondence: \\ Dr. Chandramathi Majety, \\ E-mail: chandra.543@rediffmail.com
}

Copyright: () the author(s), publisher and licensee Medip Academy. This is an open-access article distributed under the terms of the Creative Commons Attribution Non-Commercial License, which permits unrestricted non-commercial use, distribution, and reproduction in any medium, provided the original work is properly cited.

\begin{abstract}
The progress of any nation exclusively depends on the societal status of women. Just about one half of the global population comprise of women. Women have always been sufferers of abuse by male dominated society. Men require being oriented about their sense of duty towards women and women wishes to be empowered. The position remains the same everywhere. In a country like India woman is worshipped as goddess and on the other hand she is being subjected to oppression, suppression, exploitation and ill-treated by the male dominated society. The United Nations report states that "woman constitutes half of the world population, perform nearly $2 / 3$ of works hours, receive one tenth of the world's income and own less than one-hundredth percent of the world's property." There are many probable retort to the problem of violence against women and a range of legal doctrines in which violent behavior come into sight as an issue. A wholesome legal response to crime against women might require a significantly restructured legal framework with a new approach solely for the rationale of dealing with violence against women in all its forms. "Obstetric violence" refers to acts categorized as physically or psychologically violent in the process of child birth. Obstetric care submits to the most basic maternal care. It deals itself with the concern of a woman during pregnancy, childbirth and the post-partum blues. This also involves providing information regarding the pregnancy, child birth and post-partum blues. Indian Public Health Standards guides 'emergency obstetric care' as an essential service at every government health care center. Most of the findings have decorated the situation of obstetric care in the government health facilities to be of very poor quality and the major concern of maternal mortality. Legal intervention must ensure women's reproductive rights for better implementation and monitoring of schemes and to push the government to consider reproductive rights as a part of human rights in its realization.
\end{abstract}

Keywords: Woman, Obstetric violence, Child birth, Legal intervention

\section{INTRODUCTION}

In Ancient India women had a high place of respect in the society as mentioned in Rig Veda and other scriptures. Many grammarians like Patanjali and Katyayana have suggested that women were educated in the early Vedic period; volumes can be written about the status of women and their heroic deeds. Owing to social, economic and political changes, the status of women has undergone changes. ${ }^{1}$ From 500 B.C., women's status began to decline. $^{2}$ Women in India faced confinement and limitations. ${ }^{3}$ Child marriages have come into vogue during the sixth century onwards. Many wicked and customs and traditions have stepped in which women were enslaved and tied to the boundaries of the house. ${ }^{4}$

The position of Indian Women further deteriorated in the medieval period. ${ }^{5}$ Child marriages and ban of widow remarriages became prevalent amongst many communities in India during this period. The purdah system was introduced in India by the Muslim rulers. Rajputs of Rajasthan practiced Jauhar. Devadasis were 
sexually exploited in certain parts of India. Polygamy amongst Hindus was prevalent. Muslim families, women were restricted to Zenana areas of the house. In spite of these practices women became prominent in the field of politics, literature, education and religion. The movement to secure equal rights to women has developed historically along four fronts:

- Political

- Social

- Economical

- Educational

Of all these the most important is the economic sphere. The level of economic equality and independence are the real indicators to measure the status of women in any given society.

\section{Violence against women}

Indian women through the centuries continue to linger subjugated and oppressed for the reason that society believed in the orthodox beliefs for the brunt of violence which could be domestic, public, physical, emotional and mental. Gender based violence against women are a worldwide phenomenon. There are various forms of violence against women. Sometimes it is before birth and sometimes in the adulthood and other phases of life.

\section{The UN declaration on the elimination of violence against women state that}

"Violence against women is a manifestation of historically unequal power relations between men and women" and that "violence against women is one of the crucial social mechanisms by which women are forced into a subordinated position compared with men". 6 The United Nations concerned since the organization's founding on the subject of the advancement of women's rights. Yet the disturbing global magnitude of female targeted violence was not openly acknowledged by the international community until December 1993, when the United Nations general assembly adopted the declaration on the elimination of violence against women. The core document of Beijing conference, the governments declared that "violence against women constitutes a violation of basic human rights and is an obstacle to the achievements of the objective to equality, development and peace.

The world community curved its attention to the violence and lack of respect that many women suffer during facility based child birth. In 2014, the WHO released a statement on the issue, approved by more than 80 civil society and health professional organizations worldwide. ${ }^{7}$ The statement concede to a growing body of research that shows pervasive patterns of women's ill-treatment during labour and delivery-bodily and labour abuse, overlook and rejection, humiliation and punishment, coerced and forced care in an array of health facilities from basic rural wellbeing centres to tertiary care hospitals. Moreover, the proclamation characterizes this ill-treatment as a human rights violation. It affirms: "Every woman has the right to the highest attainable standard of health, which includes the right to dignified, respectful health care throughout pregnancy and child birth". The WHO declaration and the strong backing mark a vital turn in world maternal rights advocacy. It is a turn from the general health world of systems and resources in thwarting mortality to the close clinical setting of patient and provide in ensuring courteous care. Attention on women's experiences of abuse and disrespect during facility-based childbirth opens new opportunities for maternal rights advocacy, including an commitment with bioethics and childbirth, but because it has to be inclined to focus on micro-ethical divergence within patient-provider relations and the utilization of new technology in clinical settings, it was of modest significance to human rights in safe motherhood, which was conventionally anxious with public health policies and programmes to reduce maternal death. ${ }^{8}$ The move of maternal rights advocacy into the scientific and clinical setting creates an opportunity to link bioethics and human rights in multiple ways.

\section{Obstetric violence}

"Obstetric violence" to speak on, deals with those acts which are classified as physically or psychologically violent in the context of labour and birth. Birth takes place in progressively more medicalized environment in developed and developing countries with plentiful surgical interventions that women are sometimes forced to accept or sometimes they are done even without her consent. Birthing using medicalized practices and intrusions such as caesarean sections, episiotomies and hormonal birth induction, these practices must be restricted to those cases where there is imminent danger or threat to life of the baby or the mother, are all the time more which is being used during births which are otherwise to take place naturally. The present day scholars and Human Rights advocates consider this as a violent act against woman and her child.

Obstetric violence also involves unfounded use of instruments and movements that are predictable as risky and can lead to mortality of the mother and baby, or whose advantages and the risks have not been adequately looked at use of forceps, Kristeller maneuver, vacuum extraction. ${ }^{9,10}$ The WHO had warned that the tremendous increase in unnecessary surgeries is jeopardizing women's health and the caesarean sections have reached increased proportions in many countries and influence of financial incentives for the doctors and hospitals too cannot be ruled out sometimes. ${ }^{11}$ Concerning episiotomies, WHO has put in the picture that they might carry a greater risk of getting infected, and can cause a higher blood loss too and to limit the use of episiotomy to strict indications has a number of advantages: ${ }^{12}$

- Less posterior perineal trauma 
- Less need for suturing

- Fewer complications

England's National Health Service enlightens that episiotomies are likely to cause pain and suffering and discomfort for the woman for many months after the child birth, American Congress of obstetricians and gynecologists also recommends a restriction on their use. $^{13,14}$

The World Health Organisation stated that "in giving normal birth, there must be a valid reason to interfere with the natural process. The endeavour of care is to achieve a healthy mother and child with the least possible medical intervention compatible with the safety. ${ }^{15}$ According to the WHO, practices that must be stopped in normal labour are:

- Shaving the pubic hair

- Giving an enema to empty the bowels

- $\quad$ Electronic fetal monitoring

- Not letting the woman to eat or drink

- Telling the women to hold her breath and push during the second stage of labour (instead to leave it to her own way)

- Stretching and interfering with the entrance to the vagina when the baby is being born

- Episiotomy

- Taking the baby away from its mother at birth

- Getting the woman to lie down on her back during labour /or delivery

\section{Human rights in facility-based child birth}

1987 onwards, the safe motherhood initiative brought attention to the gross global imbalance of maternal death. ${ }^{16}$ The scheme reframed the subject from one of human tragedy to human failure by emphasizing the most maternal deaths could be prevented by ensuring access to skilful birth attendance and emergency obstetric care, both time and again addressed by encouraging women to deliver in health facilities. In mid-1990, this human failure brought significant changes as a human rights violation. It was widely attributed that under International Law, women can boast to have an enforceable right to survive pregnancy and childbirth. Human rights in safe motherhood drove an innovative age of advocacy. ${ }^{17}$ The UN Human Rights council has issued notable declaration on maternal mortality and human rights. ${ }^{18}$ Reproductive justice advocates can litigate the cases under regional and UN human rights agreement in efforts to enforce these rights. ${ }^{19}$

For the first time in 2011, under human rights treaty body held a nation accountable under International Law for an avertable maternal death. The case, Alyne da Silva Pimental Yeieira V. Brazil, concerned a Brazilian woman of African descent who died as result of obstetric difficulty while seeking care in multiple health facilities. $^{20}$ The United Nations Committee on the elimination of discrimination against women, measured the case, found that Brazil failed to make sure that proper services in "connection with pregnancy, confinement and the post natal period" in violation of the rights to health, life, and non-discrimination. ${ }^{21}$ The case is significant because of its broad definition of quality of care. The human rights violation involved more than technical breaches of clinical standards. The United Nations Committee on elimination of discrimination against women focused on the negligence and discrimination that differentiate the experience of Afro-Brazilian women in seeking facility based maternity care. The committee also highlighted the humiliation of being forced to travel from one hospital to another hospital in search of facility care and finally was left to die unattended in a provisional area of a hospital hallway. This case reflects a vital shift in maternal rights advocacy. Global Investigation on abuse and disrespect in facility based child birth has risen in the recent years, instructing a widespread phenomenon. Women still continue to die in child birth because of low facilities during labour and delivery, or for the reason that they are driven away from facility based delivery for fear of mistreatment. ${ }^{22}$ Concentration in advocacy has shifted beyond a certain facility delivery to ensuring its quality of care, and to a beginning of quality beyond technical and clinical competence to respectful and humane treatment. Such anxiety is neither new nor novel, at least for the countries which have longer histories of facility based birth. Now the global movement intensified the use of International Human Rights Law to advocate for a transformation.

\section{The 2011 charter on respectful maternity care}

White Ribbon Alliance, a global network of maternal health advocates ${ }^{23}$ drafted The Universal rights of childbearing women and the charter seek out to make superior the concept of safe motherhood ahead of the prevention of death and disability, and the human rights scrutiny beyond a right of access to health services. In mentioning about the right to health, the Charter lays emphasis on dimensions of respect, dignity, noncoercion, and non-discrimination in health care delivery.

Assertion of the Universal Rights of Childbearing, Women Human rights are fundamental entitlements due to all people, recognized by societies and governments and enshrined in international declarations and conventions. Till date, no universal charter or instrument specifically demarcate how human rights are implicated in the childbearing process or affirms their application to childbearing women as basic, inalienable human rights. This Charter intends to address the issue of abuse and disrespect among women looking for maternity care and make available a platform for progress and expansion by raising awareness of childbearing of women inclusion in the guarantees of human rights recognized in, Internationally adopted United Nations and other multinational declarations, conventions, and covenants; 
Maternity related care. Human rights society standards; privilege to high-quality maternity care with international guidelines Providing a basis for holding the maternal care system and communities responsible to these rights.

\section{Obstetric violence in India}

Obstetric violence, the mistreatment of pregnant women by health workers and doctors is shamefully common in the Indian medical system though it is rarely spoken about. Ironically in India violation of reproductive rights is not yet considered a human rights issue. In the Balia's case, the National Human Rights Commission (NHRC) has taken a suo motu action and issued notices to the state government and concerned officials. Obstetric Violence is not limited to villages or towns, it happens in urban cities as well. One intern jolted up a storm when he blogged in December 2013 that "in an Indian government hospital a woman giving birth to a child is not a unit less than suffering third degree torture in jails. Pregnant women are beaten like anything and, worst of all, the doctors feel it's completely justified. Medicines like Buscopan and Drotaverine are administered to speed up the labour and unwanted episiotomies with accompanying fundal pressure manoeuvres leaves the woman perplexed. In one shocking incident nurses in a hospital in Delhi threatened to slap a pregnant woman if she screamed during labour and handed her the unwashed body of her still born baby in a plastic bag. The HRLNthe human rights law network filed a case in the Delhi High Court, which ordered the government to pay Rs. 10,000 to the mother as an interim measure and posted it for the next hearing in January 2016.

In India, "the baby friendly hospital initiative is well known, but it is weird that our system never gave serious consideration in making the health centres motherfriendly. There is a per phrase "skilled birth attendance"that getting woman give birth in hospitals instead of homes satisfies the "skilled birth attendance" recommendation of the World Health Organisation. But then, does that mean that the support woman becomes skilled in the clinical aspect? The answer is No; skills like compassion and humanity are consistently essential and painfully lacking in our hospitals. Obstetric violence in India seems par for the course with very few people questioning common birthing practices. Which are:

- Physical exam

- Medication to induce labour

- Labour positions

- C-sections

- Stitches, stitches and more stitches

- Formula feeding

HRLN, a collective of lawyers and social activists, has filed 150 cases in 14 states regarding violation of reproductive rights. "The health sector has had massive budget cuts at the central level and under-spending at the state level, which has led to a shrinking of the public health sector and perennial shortage of doctors and health personnel. There is also a prevalent attitudinal problem towards the poor, but it is wrong to fix the blame at the lower level of health providers such as nurses and ward attendants.

Schemes like the Janani Suraksha Yojana, which pays pregnant women to give birth in health facilities and health workers for bringing them in, have pushed up institutional deliveries from $40 \%$ to about $80 \%$. However, this gush in institutional deliveries - targeted as a means of reducing maternal mortality - has not seen a proportionate increase in investment by the Government in public health facilities. This often means shortage of staff and poorly trained personnel.

Abuse by health workers in maternity care is not exceptional to India. Little wonder that the World Health Organisation (WHO) found it necessary to issue a proclamation on preventing and eliminating disrespect and abuse during childbirth. "Public health personnel necessitate seeing the delivery of care as their duty and a patient's right. In their training, there must be sensitizing about gender and imparting of soft skills -like to engage with patients, but incidentally and sad to note that there is no training of that kind said Dr Sandhya. "24 "The terms of abuse used against pregnant women are shockingly similar across the world. It may possibly be something to do with how we view reproduction and women." The high court of Madhya Pradesh has passed a landmark judgment in a case, recognizing that a woman's right to survive pregnancy and child birth is a fundamental right protected under Article 21 of the Indian Constitution. ${ }^{25}$

\section{CONCLUSION}

Challenges are vast and frequent and calls for immediate action and in assessing the current state of the world's women maternal mortality is clear that we have made grossly insufficient progress in addressing one of the most persistent and dangerous forms of violence. It is incumbent upon governments, citizens, armies, police, families, medical centres, neighbours, educators, and organizations, among others, to intensify efforts to establish accountability for the obstetric violence directed against half the world's population. The International Organisations like United Nations, countries, and donors must invest far more resources and energy into tackling this loathsome botheration. International and domestic laws intended to protect women against obstetric assault must be enforced and governments held accountable for their failures to protect, investigate, and prosecute violence committed against their citizens or on their territory, including the state agents.

It is deeply disturbing that a broad range of obstetric violence continues to thrive, and it is equally challenging that these crimes have a low likelihood chance of receiving any form of liability. If we are to include any hope of improvement for future generations, we must invest appreciably more efforts to prevent and punish these crimes, and make legislations addressing them a priority. It will not be easy in the face of terrorism, wars, 
religious extremism, archaic attitudes, propaganda and indifference. But we must persevere, for the sake of humanity.

Funding: No funding sources

Conflict of interest: None declared

Ethical approval: Not required

\section{REFERENCES}

1. Varttika by Katyayana, 125, 2477. Availbale from: http://orkut.google.com/c87247562t56bc9529118c925c478380248ae58a6e.html.

2. Jayapalan. Indian Society ND Social Institutions. Atlantic Publishers and Distributer; 2001:145.

3. Kamat K. Status of women in medieval Karnataka; 2006. Availbale from: http://www.kamat.com/jyotsna/women.htm. Retrieved 2006-12-24.

4. Goel A. Violence and protective measures for women development and empowerment. New Delhi, Deep and Deep Publications; 2004:3-4.

5. Women in History. National Resource Center for Women. Archived from the original on; 2009.

6. A/RES/48/104-Declaration on the elimination of violence against women. United Nations General Assembly; 2006.

7. World Health Organisation, The prevention and elimination of disrespect and abuse during facilitybased childbirth. WHO/RHR/14.23. Geneva: World Health Organisation; 2014.

8. Dickens BM, Cook RJ. Reproductive health and public health ethics. International Journal of Gynecology and Obstetrics 99/1; 2007:75-9. Farmer and NG Campos, New malaise: bioethics and human rights in the global era, Journal of Law, Medicine and Ethics 32/1. 2004;243-251.

9. Habek D, Bobić MV, Hrgović Z. Possible fetomaternal clinical risk of the Kristeller's expression. Cent Eur J Med. 2008;3(2):183-6.

10. Riyami NA, Shezawi FA, Al-Ruheli, Al-Dughaishi T, Al-Khabori M. Perinatal Outcome in Pregnancies with Extreme Preterm Premature Rupture of Memranes (Midtrimester PROM). Sultan Qaboos Univ Med J. 2013;13(1):51-6.

11. World Health Organization. Care in normal birth: a practical guide. 1996.

12. NBC News. C-section rates around the world at epidemic levels. World Health organization Reproductive Health Library. Episiotomy for Vaginal Birth National Health Services, United Kingdom.'NHS Choices: Episiotom. Available from: http://www.nbcnews.com/id/ 34826186/\#.V8AB9Vt97IU

13. The American Congress of Obstetricians and Gynecologists (March 31, 2006). ACOG Recommends Restricted Use of Episiotomies.
14. Jilly R. World Health Organisation Publications. Availbale from: http://www.int/chd/publications/newlet/dialog/8/keep ing_birth_normal.htm.

15. Zahr CA. Safe motherhood: a brief history of the global movement 1947-2002. British Medical Bulletin. 2003;67:13-25.

16. Cook R, Dickens B. Advancing safe motherhood through human rights (Geneva: WHO; 2000).

17. Yamin A. From ideals to tools: Applying human rights to maternal health," PLOS Medicine 10/11. 2013; e1001546.

18. United Nations Human Rights Council, Preventable maternal mortality and morbidity and human rights, General Assembly, Eleventh session; 2009.

19. A/HRC/11/L.16/Rev.1; United Nations Human Rights Council, Preventable Maternal Mortality and Morbidity and Human Rights, Eighteenth Session; 2011.

20. Hungary AS. Communication No. 4/2004, CEDAW/C/36/D/4/2004, and F.S. v. Chile, admitted to the Inter- American Commission of Human Rights, September 2014. See also: Center and Vivo Positivo, Dignity denied: Violations of the rights of HIV-positive women in Chilean health facilities New York: Center for Reproductive Rights; 2010.

21. da Silva Pimentel v Brazil. Committee on the Elimination of Discrimination against Women. Communication No. 17/2008. CEDAW/C/49/D/17/ 2008. Decision of 25 July, 2011. See also: R.J. Cook, Human rights and maternal health: Exploring the effectiveness of the Alyne decision. Journal of Law, Medicine and Ethics 41/1; 2013:103-123.

22. International Convention on the Elimination of All Forms of Discrimination against Women, G.A. Res. 34/180. 1979:12(2).

23. Mathai M. To ensure maternal mortality is reduced, quality of care needs to be monitored and improved alongside increasing skilled delivery coverage rates. BJOG. 2011;118(Supp2):12-14.

24. Radoff KA, Levi A, Thomson LM. From home to hospital: mistreatment of childbearing women and barriers to facility-based birth in Nicaragua," International Journal of Childbirth 2/1. 2012;40-50.

25. White Ribbon Alliance, Respectful Maternity Care: The Universal Rights of Childbearing Women. Washington, DC: White Ribbon Alliance; 2011. Available at http://whiteribbonalliance.org/wpcontent/uploads/2013/10/ Final_RMC_Charter.pdf.

26. Sandhya YK. Of Sahyog, an organization working to promote gender equality and women's health from a human rights framework.

27. Sandesh Bansal v. Union of India (PIL) W.P. 9061/2008.

Cite this article as: Majety $\mathrm{C}$, Bejugam $\mathrm{S}$. Challenges and barriers faced by women in accessing justice against obstetric violence. Int $\mathbf{J}$ Reprod Contracept Obstet Gynecol 2016;5:28992903. 